\title{
Influence of a High Ambient Temperature and Dietary Fat Supplementation on Fatty Acid Composition of Depot Fats in Finishing Pigs
}

\author{
Masaya Katsumata, Hideaki Hirose*, Yuji KaJI \\ and Mamoru SAITOH** \\ Kyushu National Agricultural Experiment Station, \\ Nishigoshi-machi, Kumamoto-ken 861-11 \\ * Oita Prefecturai Oita Livestock Hygiene Service \\ Center, Oita-shi 870-11 \\ ** National Institute of Animal Industry, Tsukuba \\ Norin Kenkyu Danchi, Ibaraki-ken 305
}

(Received August 4, 1994)

\begin{abstract}
Sixteen finishing barrows, weighing initially $85 \mathrm{~kg}$, were divided into 4 experimental treatments in a $2 \times 2$ factorial arrangement to determine the effects of a high ambient temperature $\left(30^{\circ} \mathrm{C}\right.$ vs. $\left.18^{\circ} \mathrm{C}\right)$ and dietary fat supplementation $(10 \%$ of encapsulated-tallow supplementation vs. $0 \%$ ) on fatty acid composition of body fat. After 4 weeks of the feeding trial, pigs were slaughtered. Outer and inner layers of the backfat and the leaf fat were obtained as samples from the left half of carcass, and fatty acid composition of the fat samples was determined. Principal component analysis on fatty acid composition of the fat samples indicated that ratios of the total percentage of monounsaturated fatty acids to that of saturated fatty acids (M/S ratio) and precentages of oleic and linoleic acid represented difference in fatty acid composition in this study. M/S ratios of the outer layer of the backfat and that of the leaf fat were significantly lower at a high ambient temperature $(\mathrm{P}<0.05)$. Percentages of oleic acid were significantly lower at a high ambient temperature $(\mathrm{P}<0.05)$. Percentage of linoleic acid of the leaf fat was significantly higher $(\mathrm{P}<0.05)$ and that of the outer layer of the backfat tended to be higher $(\mathrm{P}<$ 0.10 ) at a high ambient temperature. Melting points of the backfat samples were significantly lower in pigs fed the fat supplemented diet $(\mathrm{P}<0.01)$, while those of the leaf fat were not affected by dietary far supplementation. The possible mechanisms by which a high ambient temperature affected fatty acid composition of depot fats of pigs were discussed.
\end{abstract}

66 (3) : 225-232, 1995 Anim. Sci. Technol. (Jpn.)

Key words : high ambient temperature, dietary fat supplementation, fatty acid composition, pigs

Several factors such as ditary composition, age, sex, site of fat deposition and environmental temperature affect fatty acid composition of depot fats of finishing pigs $\mathrm{s}^{4,7,8,10,11)}$. In particular, heat exposure resulted in low degree of unsaturation of depot fats compared with exposure to cold or thermoneutral temperature ${ }^{7,10,11)}$. ICHIKAWA et al. ${ }^{7)}$ reported that the supplementation of beef tallow to diet of fattening pigs enhanced percentage of linoleic acid of body fat during summer season although the supplementation did not affect it during winter season. Therefore it seems that the influence of dietary fat on fatty acid com- 
postion of body fat of pigs is affected by environmental temperature. LEFAUCHEUR et al. ${ }^{10)}$ observed that the extent of unsaturation of depot far of finishing pigs was lower at $28^{\circ} \mathrm{C}$ than at $12^{\circ} \mathrm{C}$. Moreover, they observed the suppression of activities of lipogenic enzymes such as malic enzyme and glucose 6-phosphate dehydrogenase of the adipose tissue of pigs at $28^{\circ} \mathrm{C}$. However, it was not elucidated whether the lower activities of the enzymes affected the extent of unsaturation of depot fat of pigs at a high ambient temperature. As described above, it is likely that high ambient temperature affects fatty acid composition of depot fat of pigs, in particular resulting in lesser extent of unsaturation of it. However, the mechanisms by which high ambient temperature affects fatty acid composition of depot fat of pigs have not been elucidated yet.

This study was conducted to determine the influence of a high ambient temperature and dietary fat supplementation on fatty acid composition of depot fat of finishing pigs. In addition, we discuss the possible mechanisms by which a high ambient temperature affects fatty acid composition of depot fats in pigs in this report.

\section{Materials and Methods}

Sixteen barrows of which average intitial body weight was $85 \mathrm{~kg}$ were divided into 4 groups, high temperature fed on a fat supplemented diet group $\left(30^{\circ} \mathrm{C}\right.$ fat group, $\left.\mathrm{n}=4\right)$, high temperature fed on the control diet group $\left(30^{\circ} \mathrm{C}\right.$ cont. group, $\left.\mathrm{n}=4\right)$, thermoneutral temperature fed on the fat supplemented diet group $\left(18^{\circ} \mathrm{C}\right.$ fat group, $\left.\mathrm{n}=4\right)$ and thermoneutral temperature fed on a control diet group $\left(18^{\circ} \mathrm{C}\right.$ cont. group, $n=4$ ). The detail of procedure of the feeding trial was described in our previous paper $^{9)}$. During a 2 week prelimainary period, all barrows were fed a control diet at $18^{\circ} \mathrm{C}$. After the period, the barrows were reared at each environmental temperature for 4 weeks. They were allowed free access to the diets and water, and reared individually in an air-conditioned room in our experiment station throughout the experiment period. The room temperature and the relative humidity of the $30^{\circ} \mathrm{C}$ fat and the $30^{\circ} \mathrm{C}$ cont. groups were $30 \pm$ $0.5^{\circ} \mathrm{C}$ and $55 \pm 5^{\circ} \mathrm{C}$, respectively, and those of the $18^{\circ} \mathrm{C}$ fat and $18^{\circ} \mathrm{C}$ cont. groups were $18 \pm 0.5^{\circ} \mathrm{C}$ and $55 \pm 5 \%$, respectively.

The compositions of diets are shown in Tables 1 and 2. The supplemented fat was encapsulated-tallow, which was purchased from Nagase Biochemicals Limited, Kyoto, Japan. All the barrows were slaughtered at Cooperation Kumamoto Meat Distribution Center after overnight fasting. Outer layer and inner layer of backfat, and leaf fat of the left side of carcasses were obtained as samples. They were stored at $-20^{\circ} \mathrm{C}$ until determination of fatty acid composition.

Fatty acid composition of the fat samples was determined according to the method $d y$ CHIKunI et al. ${ }^{4}$. A $100 \mathrm{mg}$ of fat sample was minced in $1 \mathrm{~g}$ of sodium sulfate anhydrous in 10 $\mathrm{m} l$ test tube, and total lipid was extracted with $4 \mathrm{~m} l$ of chloroform. The chloroform extract was dried under nitrogen gas stream at $50^{\circ} \mathrm{C}$,

Table 1. Composition of experimental diets (\%)

\begin{tabular}{lcc}
\hline \hline & $\begin{array}{c}\text { Fat supple- } \\
\text { mented diet }\end{array}$ & $\begin{array}{c}\text { Control } \\
\text { diet }\end{array}$ \\
\hline Corn & 58.6 & 69.5 \\
Soybean meal & 25.3 & 23.8 \\
Barley bran & 3.1 & 3.7 \\
Encapsulated tallow & 10.0 & none \\
Tricalcium phosphate & 2.0 & 2.0 \\
Sodium chloride & 0.5 & 0.5 \\
Vitamin and mineral mixture* & 0.5 & 0.5 \\
\hline \multicolumn{1}{c}{ Total } & 100.0 & 100.0 \\
\hline
\end{tabular}

* Providing (per $\mathrm{kg}$ diet) : retinol $3 \mathrm{mg}$, cholecalciferol $50 \mu \mathrm{g}, \mathrm{DL}-\alpha$-tocopheryl acetate $10 \mathrm{mg}$, thiamin $2 \mathrm{mg}$, riboflavin $14 \mathrm{mg}$, pyridoxine $\mathrm{HCl} 1.0 \mathrm{mg}$, pantothenic acid $21 \mathrm{mg}$, nicotinic acid $12 \mathrm{mg}$, choline $115 \mathrm{mg}$, Mn $100 \mathrm{mg}$ (manganese carbonate), $\mathrm{Zn} 120$ $\mathrm{mg}$ (zinc carbonate), $\mathrm{Cu} 20 \mathrm{mg}$ (copper sulfate), $\mathrm{Fe}$ $100 \mathrm{mg}$ (iron sulfate), I $2 \mathrm{mg}$ (calcium iodate). 


\section{Fatty Acid Composition in Hot Environment}

Table 2. Analyzed composition of experimental $\operatorname{diets}(\%)$

\begin{tabular}{ccc}
\hline \hline & $\begin{array}{c}\text { Fat supple- } \\
\text { mented diet }\end{array}$ & Control diet \\
\hline Dry matter & 88.9 & 87.9 \\
Crude protein & 17.7 & 17.9 \\
Crude fat & 10.9 & 3.1 \\
Fatty acids & & \\
$14: 0$ & 2.1 & 0.3 \\
$16: 0$ & 23.2 & 18.9 \\
$16: 1$ & 2.6 & 1.0 \\
$18: 0$ & 13.3 & 4.5 \\
$18: 1$ & 40.0 & 30.2 \\
$18: 2$ & 18.1 & 43.2 \\
$18: 3$ & 0.9 & 2.1 \\
\hline
\end{tabular}

and methyl esterification of total lipid was carried out by addition of $2 \mathrm{ml}$ of $0.5 \mathrm{~N}$ sodium methylate in methanol at $60^{\circ} \mathrm{C}$. Total lipid extracts from experimental diets were esterificated with $5 \% \mathrm{HCl}$-methanol at $100 \mathrm{C}$ for 3 hours ${ }^{5)}$. The methyl esters were extracted with hexane and stored at $-20^{\circ} \mathrm{C}$ until analysis. Compositions of fatty acid methyl esters were determined by gas-liquid chromatography (GC-14A, Shimadzu) with a flame ionization detector. The chromatograms were recorded on a thermal-pen recorder (Chromatopack C-R 5 A, Shimadzu). A capillary column was used for the analysis: $50 \mathrm{~m}$ long and $0.25 \mathrm{~mm}$ i.d. (WCOT fused silica, CP-Sil 88 from Chrompack, The Netherlands). The operation conditions were according to Ail et al. ${ }^{1}$. Melting points of the fat samples were measured by the capillary tube method ${ }^{3)}$.

Statistical analysis was carried out as follows. Principal of fatty acid composition of the fat samples were analyzed by PRINCOMP procedure of $\mathrm{SAS}^{13)}$. Influence of a high ambient temperature and dietary fat supplementation were analyzed by 2 way analysis of variance, $2 \times 2$, by GLM procedure of $\mathrm{SAS}^{13}$.

\section{Results}

All data of fatty acid composition of the fat samples, $n=48$ for each fatty acid, were used for principal component analysis (Table 3 a). In addition, although data of each depot site, 16 data for each fatty acid, were also analyzed, the result of analysis on the inner layer of the backfat is presented in Table $3 \mathrm{~b}$ bacause its result is the most comprehensible among three depot sites. In both cases, sums of contributions from the first components to the third components exceeded 0.95. Therefore, eigenvectors of the first, the second and the third components are shown. Eigenvectors of palmitic acid (16:0) and stearic acid (18:0) of the first components were negative, while those of myristic acid (14:0), palmitoleic acid (16:1), oleic acid $(18: 1)$ and linoleic acid (18:2) were positive (Tables $3 \mathrm{a}$ and $3 \mathrm{~b}$ ). Eigenvectors of oleic acid of the second components were negative (Tables $3 \mathrm{a}$ and $3 \mathrm{~b}$ ). An eigenvector of linoleic acid of the third component in Table $3 \mathrm{a}$ was negative, while that in Table $3 \mathrm{~b}$ was

Table 3. Eigenvectors for three principal components of major fatty acids

a, All samples

\begin{tabular}{crrr}
\hline Fatty acids & Z1 $(0.62)^{*}$ & Z2(0.24) & Z3(0.09) \\
\hline $14: 0$ & 0.10 & 0.35 & 0.38 \\
$16: 0$ & -0.45 & 0.35 & 0.02 \\
$16: 1$ & 0.42 & 0.38 & 0.08 \\
$18: 0$ & -0.51 & -0.01 & -0.09 \\
$18: 1$ & 0.42 & -0.36 & 0.49 \\
$18: 2$ & 0.40 & 0.18 & -0.78 \\
\hline
\end{tabular}

b, Inner layer of backfat

\begin{tabular}{crrr}
\hline Fatty acids & $Z 1(0.49)$ & $Z 2(0.28)$ & \multicolumn{1}{c}{$Z 3(0.19)$} \\
\hline $14: 0$ & 0.32 & 0.58 & 0.09 \\
$16: 0$ & -0.37 & 0.55 & 0.21 \\
$16: 1$ & 0.43 & 0.47 & -0.08 \\
$18: 0$ & -0.58 & 0.02 & -0.03 \\
$18: 1$ & 0.49 & -0.36 & -0.26 \\
$18: 2$ & 0.04 & 0.02 & 0.93 \\
\hline
\end{tabular}

$Z 1, Z 2$ and $Z 3:$ the first, second and third components, respectively.

* : Contributions of the each component. 
positive. However, the absolute values of eigenvectors of linoleic acid of the third components were large, 0.78 and 0.93 (Tables $3 \mathrm{a}$ and $3 \mathrm{~b}$ ). The analysis indicated that the ratio of the total percentage of monounsaturated fatty acids to that of saturated fatty acids (M/S ratio) and percentage of oleic and linoleic acid represented differences in fatty acid composition of depot fat of pigs observed in this study. Detail interpretations of these three factors are described in the section of discussion .
Influences of a high ambient temperature and dietary fat supplementation on fatty acid composition and melting point of the fat samples are presented in Table 4. No temperature $x$ diet interactions was observed. Percentages of palmitic acid were significantly higher at a high ambient temperature $(\mathbb{P}<0.05)$. On the other hand, percentages of oleic acid were significantly lower at a high ambient temperature $(\mathrm{P}<0.05)$. Percentage of linoleic acid of the outer layer of the backfat and that of the

Table 4. Influences of a high ambient temperature and a dietary fat supplementation on percentages of fatty acids, M/S ratio and melting point $\left({ }^{\circ} \mathrm{C}\right)$ of the fat samples

\begin{tabular}{|c|c|c|c|c|c|c|c|}
\hline & \multicolumn{2}{|c|}{ Temp. } & \multicolumn{2}{|c|}{ Diet } & \multirow{2}{*}{ SEM } & \multicolumn{2}{|c|}{ Level of significance } \\
\hline & $30^{\circ} \mathrm{C}$ & $18^{\circ} \mathrm{C}$ & Fat & Cont. & & Temp. & Diet \\
\hline \multicolumn{8}{|c|}{ (Outer layer of backfat) } \\
\hline $14: 0$ & 1.5 & 1.5 & 1.6 & 1.5 & 0.1 & N.S. & N.S. \\
\hline $16: 0$ & 26.4 & 25.3 & 25.3 & 26.4 & 0.9 & $*$ & * \\
\hline $16: 1$ & 2.9 & 2.7 & 2.8 & 2.8 & 0.3 & N.S. & N.S. \\
\hline $18: 0$ & 12.6 & 11.3 & 11.7 & 12.2 & 1.1 & * & N.S. \\
\hline $18: 1$ & 44.1 & 47.6 & 46.6 & 45.1 & 1.2 & $* * *$ & * \\
\hline $18: 2$ & 11.8 & 10.8 & 11.3 & 11.3 & 1.0 & $\dagger$ & N.S. \\
\hline$M / S^{3}$ & 1.21 & 1.38 & 1.34 & 1.25 & 0.09 & $* *$ & $t$ \\
\hline$M P^{b}$ & 31.9 & 30.5 & 27.8 & 34.5 & 2.1 & N.S. & $* * *$ \\
\hline \multicolumn{8}{|c|}{ (Inner layer of backfat) } \\
\hline $14: 0$ & 1.5 & 1.4 & 1.5 & 1. 4 & 0.1 & N.S. & N.S. \\
\hline $16: 0$ & 28.1 & 26.5 & 26.7 & 27.9 & 1.0 & $* *$ & $*$ \\
\hline $16: 1$ & 2.3 & 2.1 & 2.3 & 2.1 & 0.4 & N.S. & N.S. \\
\hline $18: 0$ & 15.7 & 14.4 & 14.4 & 15.7 & 2.0 & N.S. & N.S. \\
\hline $18: 1$ & 42.6 & 45.6 & 44.7 & 43.6 & 2.7 & $*$ & N.S. \\
\hline $18: 2$ & 9.0 & 9.0 & 9.6 & 8.4 & 1.0 & N.S. & * \\
\hline $\mathrm{M} / \mathrm{S}^{\mathrm{a}}$ & 1.04 & 1.17 & 1. 15 & 1.06 & 0.13 & $\dagger$ & N.S. \\
\hline $\mathrm{MP}^{\mathrm{b}}$ & 38.3 & 35.2 & 34.9 & 38.6 & 1.8 & ** & $* *$ \\
\hline \multicolumn{8}{|c|}{ (Leaf fat) } \\
\hline $14: 0$ & 1.6 & 1.5 & 1.6 & 1.5 & 0.1 & $\dagger$ & N.S. \\
\hline $16: 0$ & 30.0 & 28.6 & 29.0 & 29.6 & 0.9 & $*$ & N.S. \\
\hline $16: 1$ & 2.0 & 1.8 & 2.1 & 1.7 & 0.3 & N.S. & $*$ \\
\hline $18: 0$ & 18.9 & 18.4 & 18.1 & 19.2 & 1.5 & N.S. & N.S. \\
\hline $18: 1$ & 38.1 & 42.1 & 41.3 & 39.6 & 2.0 & $* *$ & N.S. \\
\hline $18: 2$ & 8.1 & 6.9 & 7.3 & 7.7 & 1.1 & $*$ & N.S. \\
\hline$M / S^{a}$ & 0.84 & 0.93 & 0.93 & 0.85 & 0.07 & $*$ & + \\
\hline $\mathrm{MP}^{\mathrm{b}}$ & 43.1 & 42.4 & 42.5 & 43.0 & 1.4 & N.S. & N.S. \\
\hline
\end{tabular}

All values are least square means. ${ }^{a}$ : Ratio of monounsaturated fatty acids to saturated fatty acids, ${ }^{b}$ : Melting point of the fat samples. ${ }^{* * *} \mathrm{P}<0.001,{ }^{* *} \mathrm{P}<0.01,{ }^{*} \mathrm{P}<0.05, \dagger \mathrm{P}<0.10$. 
Fatty Acid Composition in Hot Environment

leaf fat were higher at a high ambient temperature $(\mathrm{P}<0.1$ and $\mathrm{P}<0.05)$. Dietary fat supplementation resulted in a decrease in percentage of palmitic acid in the outer and inner layer of the backfat $(\mathrm{P}<0.05)$. Percentage of oleic acid in the outer layer of the backfat was significantly higher in the pigs fed the fat supplemented diet $(\mathrm{P}<0.05)$.

$\mathrm{M} / \mathrm{S}$ ratio of the outer layer of the backfat and that of the leaf fat were significanlty lower at a high ambient temperature than at a thermoneutral temperature $(\mathrm{P}<0.01$ and $\mathrm{P}<$ 0.05). Although the difference was not highly significant, $M / S$ ratio of the inner layer of the backfat was lower at a high ambient temperature $(\mathrm{P}<0.1)$. Melting points of the fat samples of the pigs fed the fat supplemented diet were significantly lower in the outer and inner layer of the backfat $(P<0.01)$, while that in the leaf fat were not affected by the dictary fat supplementation.

\section{Discussion}

ChrKuni $e t a l^{4)}$ investigated factors affecting fatty acid composition of depot fats of pigs through principal component analysis. In their study, they concluded that the $\mathrm{M} / \mathrm{S}$ ratio and percentage of linolcic acid were better methods to compare the difference of fatty acid composition in depot fats of pigs. In the present study, eigenvectors of palmitic and stearic acid were negative in the first components (Tables $3 \mathrm{a}$ and $3 \mathrm{~b}$ ). Furthermore, they had similar absolute values. Palmitoleic and oleic acid had similar positive eigenvectors in the first components. Therefore, it seems that the first components are factors which reduce percentage of saturated fatty acids and enhance those of monounsaturated fatty acids. Hence, as reported by CHIKUNI et $a l^{4}{ }^{4}$, it is likely that the first components are factors affecting the $\mathrm{M} / \mathrm{S}$ ratio in the present study. Although myrisitic acid is a saturated fatty acid, we did not take accunt of it when we calculated $\mathrm{M} / \mathrm{S}$ ratios since eigevectors of it were positive.
An eigenvector of linoleic acid in the first component in Table $3 \mathrm{a}$ was 0.40 , while that in Table $3 \mathrm{~b}$ was 0.04 . It means that each first component does not show the same characteristic with respect to linoleic acid. Hence, it is unlikely that the difference in percentage of linoleic acid contributes to the characteristics of the first components.

In the second components, eigenvectors of oleic acid were negative and identical $(-0.36)$. On the other hand, most of the other eigenvectors were positive in the second components. Although the eigenvector of stearic acid in Table $3 \mathrm{a}$ was negative, contribution of this fatty acid can be neglected because the absolute value was small (0.01). Hence, it seems that the second components are factors affecting percentage of oleic acid.

Eigenvectors of linoleic and stearic acid in the third components in Table 3 a were negative, and those of linoleic and myristic acid in Table $3 \mathrm{~b}$ were positive. In addition, although the absolute values of eigenvectors of linoleic acid were large (0.78 and 0.93 ), those of stearic and myristic acid were small (0.09). Therefore, it seems that the third components are factors affecting percentage of linoleic acid in the fat samples.

Consequently, differences in fatty acid composition under the influence of the treatments in this study are represented by $\mathrm{M} / \mathrm{S}$ ratio and percentage of oleic and linoleic acid.

PELUFFo and BRENNER ${ }^{12)}$ observed that activities of both $\Delta 6$ desaturase and $\Delta 9$ desaturase in liver microsomes of rats were suppressed at a high ambient temperature. In addition, when they exposed rats adapted to a high ambient temperature to a low ambient temperature, the activity of $\Delta 6$ desaturase was increased ${ }^{12)}$. From these results, it appears that a high ambient temperature resulted in a decrease in activities of fatty acid desaturase. Moreover, ChIKuni et al. ${ }^{4)}$ pointed out that lower M/S ratio of depot fats of pigs indicated lower activity of $\Delta 9$ desaturase. Since $M / S$ 
ratios were lower in the $30^{\circ} \mathrm{C}$ groups in this study, it seems that activity of $\Delta 9$ desaturase in depot fats of pigs were lower at $30^{\circ} \mathrm{C}$ than at $18^{\circ} \mathrm{C}$. Significantly lower percentage of oleic acid in the fat samples at a high ambient temperature may also relate to lower activity of $\Delta$ 9 densaturase in depot fats of pigs. However, since the experimental diets contained considerable amount of oleic acid, it is unlikely that only activity of $\Delta 9$ desaturase affected percentage of oleic acid in depot fats of pigs at a high ambient temperature.

Percentage of linoleic acid of the outer layer of the backfat and that of the leaf fat were higher at a high ambient temperature in this study. In addition, when we investigated the influence of a high ambient temperature on percentage changes in fatty acid composition of the outer layer of the backfat in the latest our experiment, the increase in percentage of linoleic acid during the 4 weeks of test period was significantly higher at a high ambient temperature than at a thermoneutral temperature (unpublished data). Percentage of linoleic acid in depot fats of pigs can be used as an indicator of de novo fatty acid synthesis rate in the adipose tissue of pigs $^{4)}$. It means that higher percentage of linoleic acid, which is an essential fatty acid, indicates lower fatty acid synthesis rates in the tissue. LeFaucheur et $a l{ }^{10)}$ also observed that percentage of linoleic acid of the outer layer of the backfat were significantly higher in pigs reared at $28^{\circ} \mathrm{C}$ than in those reared at $12^{\circ} \mathrm{C}$. Moreover, they simultaneously observed that activities of malic enzyme and glucose 6-phosphate dehydrogenase of the outer layer of the backfat of pigs were significantly lower at a high ambient temperature. This result indicated that de novo fatty acid synthesis rate was suppressed at a high ambient temperature. Furthermore, as indicated by the reports of PELUFFo and BRENNER ${ }^{12)}$ and Gonzalez et $a l^{6}{ }^{6}$, a high ambient temperature might cause a decrease in activities of $\Delta 6$ desaturase in the fat samples. Therefore, it is possible to attribute higher percentage of linoleic acid in the $30^{\circ} \mathrm{C}$ groups to lower de novo fatty acid synthesis rates and/or lower activities of $\Delta 6$ desaturase in the pigs reared at $30^{\circ} \mathrm{C}$. However, the reason a high ambient temperature did not affect percentage of linoleic acid of the inner layer of the backfat is unknown.

Analysis of variance indicated that melting points of the fat samples from the dietary fat supplemtnted groups were significantly lower than those of the control diet groups in the outer and inner layer of the backfat. However, melting point of the leaf fat was not affected by the dietary fat supplementation. Average percentages of linoleic acid of the fat samples differed among depot sites (Table 4) : percentage of linoleic acid of the outer layer of the backfat was the highest and that of the leaf fat was the lowest. As already discussed above, higher contents of linoleic acid are partly caused by lower de novo fatty acid synthesis rates. Therefore, it seems that activity of $d e$ novo fatty acid synthesis differ among depot sites of fat. ANDERSON et al. ${ }^{2)}$ investigated de novo fatty acid synthesis rates of the backfat, intermuscular fat, leaf fat and leg subcutaneous fat of pigs. They observed that the synthesis rates of the leaf fat were higher than those of any other depot fat sites. In addition, LEFAUCHEUR et al. ${ }^{10)}$ also observed that activities of lipogenic enzymes of the leaf fat were significantly higher than those of the backfat. Taking these observations into consideration, it is likely that influence of dietary fat supplementation on fatty acid composition of depot fat is smaller in the leaf fat than in the backfat since de novo fatty acid synthesis rates are higher in the leaf fat than in the backfat of pigs. Consequently, dietary fat supplementation in this study did not affect melting points of the leaf fat samples.

The results obtained in the present study suggest that activities of fatty acid desaturase and de novo fatty acid synthesis rates in depot 
Fatty Acid Composition in Hot Environment

fats of pigs are suppressed at a high ambient temperature, and that changes of fatty acid composition by the treatments in this study may be attributed to the altered lipid metabolism by heat exposure. However, we did not investigate activities of fatty acid desaturase nor any lipogenic enzymes in the adipose tissue of pigs. Hence, further investigations are necessary to elucidate the influence of a high ambient temperature on acitivities of fatty acid desaturase and lipogenic enzymes.

\section{Acknowlegements}

The authors are grateful to the late Ryoichi SHIGAKI, Fusataka HAYASH, Kunihiro HASHIMoto, Hiroyuki TsuBomi, and Yasutaka NAKAHARA for their management of the experimental animals. We are also grateful to Kyoko YAMAMOTO for technical assistance and Shigirai M. MASVAURE for reviewing the manuscript.

\section{References}

1) AII, T., M. KuriHara and S. Ishida, Increase in $\alpha$-linolenic acid in milk fat by feeding the calcium soap of fatty acids prepared from linseed oil. Anim. Sci. Technol. (Jpn.), 62 : 58-62. 1991.

2) Anderson, D.B., R.G. Kauffman and L.L. KASTENSCHMIDT, Lipogenic enzyme acitvities and cellularity of porcine adipose tissue from various anatomical locations. J. Lipid Res., 13 : 593-599. 1972.

3) Association of Official Agricultural Chemists, Official methods of analysis. 15th ed. 954. Association of official agricultural chemists. Arlington. 1990.

4) Chikuni, K., M. Jinbu, S. Ozawa, T. Kolshikawa,
M. Yoshitake and N. Yano, Changes in differences of composition of fatty acids in fat of pigs by their breeds and sexes during their growth. Jap. J. Swine Science, $22: 200-205$. 1985.

5) FuJINo, Y., Shishitsu bunsekihou nyumon. 176177. Gakkai Shuppan Center. Tokyo. 1978.

6) Gonzalez, S., A.M. Nervi and R.O. Peluffo, Effects of estradiol and environmental temperature changes on rat liver 6 microsomal desaturase activity. Lipids, 21 : 440-443. 1986.

7) ICHIKAWA, A., S. Kobayashi and T. ISHIBASHI, Influence of animal fat added to feed on fatty acid composition of porcine body fat. Res Bull. Aichi Agric. Res. Ctr., $21: 320-326.1989$.

8) IRIE, M. and K. NishimurA, Influence of feeding garbage, slaughter age and depot site on characteristics of porcine fat. Jpn. J. Zootech. Sci., $57: 642-648.1986$.

9) Katsumata, M., H. Hirose, Y. Ka.I and M. SAITOH, The effects of a high ambient temperature and dietary fat supplementation of nutrient digestibility of fattening pigs. West Japan. J. Anim. Sci., 36 : 30-36. 1993.

10) Lefaucheur, L., J. Le Dividichi, J. Mourot, G. Monin, P. ECOLAN and D. Krauss, Influence of environmental temperature on growth, muscle and adipose tissue metabolism, and meat quality in swine, J. Anim. Sci., $69: 2844-2854.1991$.

11) MaCgrath, W.S., G.W. Vander Noot, R.L. GILBREATH and H. FishER, Influence of environmental temperature and dietary fat on backfat composition of swine. J. Nutr., 96 : 461466. 1968.

12) Peluffo, R.O. and R.R. BREnNER, Influence of dietary protein on 6- and 9-desaturation of fatty acids in rats of different ages and in different seasons. J. Nutr., $104:$ 894-900. 1974.

13) SAS. SAS User's Guide: Statistics (5th ED.). SAS Inst. Inc., Cary, NC. 1985. 


\title{
高温環境と飼料への油脂添加が肥育豚の体脂肪の 脂肪酸組成に及ぼす影響
}

\author{
勝俣昌也 ·廣瀬英明 * ・ 暒 雄次 · 斎藤 守 ${ }^{* *}$ \\ 農林水産省九州農業試験場, 熊本県西合志町 861-11 \\ *大分家畜保健衛生所，大分市 870-11 \\ **農林水産省畜産試験場, 茨城県筑波農林研究団地 305
}

\begin{abstract}
環境温度 $\left(30^{\circ} \mathrm{C}\right.$ と $\left.18^{\circ} \mathrm{C}\right)$ ならびに鸼料への油脂添加（10\%の粉末状夕口一添加と無添加）が, 肥育豚 の体脂肪の脂肪酸組成に及ぼす影響について検討するため，体重 $85 \mathrm{~kg}$ の去勢豚 16 頭を，2×2 の 2 元 配置の 4 試験区に配置して武験を行った. 4 週間の試駼終了後, 供試豚を屠畜し, 背脂肪の外層, 内層な らびに腎䑏脂肪を枝肉半丸よりサンプルとして採取し，脂肪酸組成の分析に供した，得られた脂肪酸 組成のデータを，主成分分析で分析したところ，本試験の処理（環境温度と飼料への油脂添加）による 体脂肪の脂肪酸組成の変動は，1価の不飽和脂肪酸と飽和指肪酸の量比 (M/S 比)の变動, オレイン酸 含量の変動, ならびにリノール酸含量の変動で代表できるむの之判断された，高温環境下では，背脂肪 外層と腎脂肪の $\mathrm{M} / \mathrm{S}$ 比が有意に低くなった $(\mathrm{P}<0.05)$.また，オレイン酸含量は高温環境下で有無に低 くなった（ $(\mathrm{P}<0.05)$ ，腎脂肪のリノール酸含量は高温環境下で有意に高く $(\mathrm{P}<0.05)$ ，背脂肪外層では 高くなる傾向を示した $(\mathrm{P}<0.10)$ ．飼料へ油脂を添加すると背脂肪外屡ならびに同内層の融点は有意に 低下したが $(\mathrm{P}<0.01)$ ，堅脂肪の融点は袖脂添加の影響を受けなかった。本試験の結果から，高温環境が 豚の体脂肪の脂肪酸組成に及ぼす影響の作用機作について考察した。
\end{abstract}

日畜会報，66 (3)：225-232，1995 